\title{
Economic and biological evaluation hybrids of Prunus cerasifera Ehrem. var. pissardii Bail. in conditions of the Southern Urals
}

\author{
Tatyana Slepneva ${ }^{1 *}$, and Sergey Makarenko ${ }^{1}$ \\ ${ }^{1}$ Ural federal agricultural research center of the Ural department of the Russian Academy of Sciences, \\ 620142, c. Yekaterinburg, Belinsky st., 112-a, Russia
}

\begin{abstract}
Given is the analysis of the basic economic and useful features of 9 genotypes $\mathrm{F}_{2}$ by hybrids of russian cherry plum (Prunus cerasifera var. pissardii) in the conditions of the forest-steppe of the southern Urals. On the research period during, three selection forms: 'Alma', G 7-116, 9266 had a degree of freezing to 1.8 mark, the others no more than 1.0 mark. During the winter period of 2017/18, the death of generative buds by all genotypes was from 2.5 to 3.0 marks $(25-50 \%$ ), which negatively affected to crop capacity. According to the results of research identified were four genotypes with weak growth of tree, which the height varies from $2.8 \mathrm{~m}$ (P 3-92) to $3.0 \mathrm{~m}$ ('Duduka'). The group of medium-sized plants got five hybrid forms, where the highest plant height $(4.5 \mathrm{~m})$ was found by the genotype 9-266 $-4.5 \mathrm{~m}$. The volume of the crown of the following forms varies from $4.2 \mathrm{~m}^{3}$ (P 3-92) to $17.8 \mathrm{~m}^{3}$ (9-266). Two genotypes have been identified for use in selection on a complex of attributes (large-fruiting, taste characteristics, crop capacity): 'Duduka', G 7-116. For the study of production was selected the sampling of the sort $G$ 7-116.
\end{abstract}

\section{Introduction}

In the selection of stone crops are valuable species and sorts with original characteristics, that can be used as genomic markers $[1,2]$. So, the anthocyanin color of leaves, controlled by the dominant gene, allows to conduct a search among the seed progeny of spontaneous hybrids in the wild and in cultivation. Such genes are possessed variety plum red-leaved (Pissarda) Prunus cerasifera Ehrem. var. pissardii Bail., which is common in the North Caucasus, especially on the Black sea coast of the Krasnodar territory and in the Crimea [3, $4,5]{ }^{\dagger}$ At the Krymsk Experiment Breeding Station, branch of the N. I. Vavilov All-Russian Institute of Plant Genetic Resources (VIR), have been identified a number of interspecific hybrids for garden and park construction. Alongside with the well-known sorts of 'Tsiteli', 'Drosha' and 'Granat' for group and alley plantings are recommended new varieties 'Zarevo', Elita 18-16-45, 'Krasnaya Strela', 'Kometa Krasnaya', 'Krasnaya Kolonna' [3,

\footnotetext{
* Corresponding author: tatyana slepneva@mail.ru
} 
4]. More low-growing sorts - 'Krasnaya Lenta', 'Krasnyj Bordyur', 'Vesennee Plamya' were promising in creating of hedges and borders. Besides from high decorative advantages, the fruits of the sorts 'Lykhny', 'Sutsumi', 'Abkhazskaya 7' and 'Alye Parusa' have high commercial qualities. As clonal rootstocks for stone crops can be used sorts: 'Krasnaya Lenta', 'Vesennee Plamya', 'Zarevo', 'Krasnaya Kometa'.

In the Nikita Botanical Gardens in selection of creature genotypes resistant to abio - and biotic stressors are involved hybrids of Prunus brigantiaca Vill. with the participation of $P$. cerasifera var. pissardii [1]. For obtaining hybrids with fruits enriched by antioxidant compounds are promising sorts with a high content of anthocyanins: 'Femida', 'Krasnomyasaya', 'Pissardi krupnoplodnaya' and others. [4]. Created are a number of intraspecific hybrids of russian cherry plum red-leaves: 'Kiziltashsardy 10-80', 'Kiziltashsardy 20-80', 'Kiziltashsardy 30-80'. Among the descendants of $F_{2}$ in the Crimea selected forms by hybrid plum red-leaves $(48-88,55-88,56-88)$ [5].

A particular value in the selection of plums in the Ural-Siberian region is $P$. cerasifera var. pissardii when hybridization with Prunus salicina subsp. ussuriensis Koval. et. Kost., what gives it possible to get new genotypes with different direction of usage of plants and their fruits: creating hardy, disease- and pest-resistant sorts with fruits, that are competitive on the market and having anthocyanin coloration of skin and pulp, as well as the creation of highly decorative sorts for landscaping in regions with inclementy climatic conditions.

As a result of analytical selection among seedlings of $P$. cerasifera var. pissardii from free pollination in 1993-1995 planting in the southern Urals be picked out five promising plants and was obtained one sort 'Zabavnitsa'. Use in selection of the choose form of P-31 (isolated from the offsprings of P. cerasifera var. pissardii) improves it the hardiness and quality fruits of new hybrids. With its participation were obtained promising plum sorts: 'Ural'skaya zheltaya', 'Ural'skaya krasnaya' and 'Ural'skij chernosliv' [6].

By M.N. Matyunin [7] in the conditions of the Middle Altai Mountains be involved $P$. cerasifera var. pissardii in the selection for resistance to the rot. The seeds were obtained from the arboretum of the Lisavenko Research Institute Of Horticulture For Siberia (Barnaul). The work was started with small-fruited forms, which the average weight did not exceeded 10-12 g. As the mother plants served the introduced P. cerasifera var. pissardii, the father's forms were local sorts of $P$. salicina subsp. ussuriensis of Altai selection. Among the descendants of F2 from repeated crossing of $P$. cerasifera var. pissardii seedlings with forms of $P$. salicina subsp. ussuriensis in the gardens in 1985-1990 planting were identified from 1.5 to $2.0 \%$ of hardy hybrids with different degrees by color of fruits, leaves and shoots.

Purpose of work - economic and biological evaluation hybrid forms of P. cerasifera var. pissardii in conditions forest-steppe of the Southern Urals, screening of sources of high adaptability, productivity and quality of fruits.

\section{Objects and methods of research.}

Objects of research - nine hybrid forms of $F_{2}$ 'Alma', 'Pissarda major', G 7-116, P 3-92, N 11-175, 9-266 (P. cerasifera var. pissardii $\times$ P. salicina subsp. ussuriensis); 'Duduka' ('Krasnomyasaya' $\times[P$. cerasifera var. pissardii $\times$ P. salicina subsp. ussuriensis $]$ ); G 8-166 (P. cerasifera var. pissardii $\times$ seedling 5-6 [free pollination of 'ZHeltoj KHopty']); G 9-146 (P. cerasifera var. pissardii $\times$ seedling 5-6 [free pollination of 'ZHeltoj KHopty']), obtained by M.N. Matyunin in the conditions of the Middle Altai Mountains.

Planting was made in 2011 for 5 plants for collection studies of sorts. Planting scheme is $5 \times 3 \mathrm{~m}$. Rootstock is the seedling of the cherry sand. The content of the soil in the rows is pure fallow, the plot is on the dry-farming land. 
The study of phenological phases of development, components crop capacity and quality of fruits, resistance to abiotic factors was carried out using a generally accepted method [8]. The pomological assessment of fruit and crown code of trees was carried out in accordance with the "Wide unified classifier CMEA of the genus Prunus L." [9]. Biometrics of trees are carryd out in view on the type of crown. The volume for spherical crown be calculated by the formula $\mathrm{V}=2 / 3 \mathrm{~V}$ cylinder, with a cylindrical crown form according to the formula $\mathrm{V}=2 / 3 \mathrm{Sh}$, where $\mathrm{V}$ - the crown volume $\left(\mathrm{m}^{3}\right), \mathrm{S}$ - the projected area of the crown $\left(\mathrm{m}^{2}\right), \mathrm{h}-$ crown height $(\mathrm{m})[10]$.

\section{Results and discussion}

During the research period (2016-2019) the climate conditions of the forest-steppe of the Southern Urals reflected all the diversity of its continentality (fig. 1), but the average annual air temperature was higher than the average long-term indications $\left(2.0^{\circ} \mathrm{C}\right)$ in 2016 by $1.7^{\circ} \mathrm{C}$, in $2017-2018$ by $0.3^{\circ} \mathrm{C}$, in 2019 by $0.8^{\circ} \mathrm{C}$. The winters of $2015 / 16$ and $2017 / 18$ were cold. The average monthly temperature in January in 2016 was lower than the long-term average $\left(-15.4^{\circ} \mathrm{C}\right)$ on $2.3^{\circ} \mathrm{C}$, and colder in 2018 on $1.3^{\circ} \mathrm{C}$. The winter of $2018 / 19$ was characterized as modestly frosty. Absolute minimum in January $2016-35.5^{\circ} \mathrm{C}\left(-38.0^{\circ} \mathrm{C}\right.$ on the snow surface), in December $2017-38.3^{\circ} \mathrm{C}\left(-42.2^{\circ} \mathrm{C}\right.$ on the snow surface) and in February $2019-37.6^{\circ} \mathrm{C}\left(-41.3^{\circ} \mathrm{C}\right.$ on the snow surface).

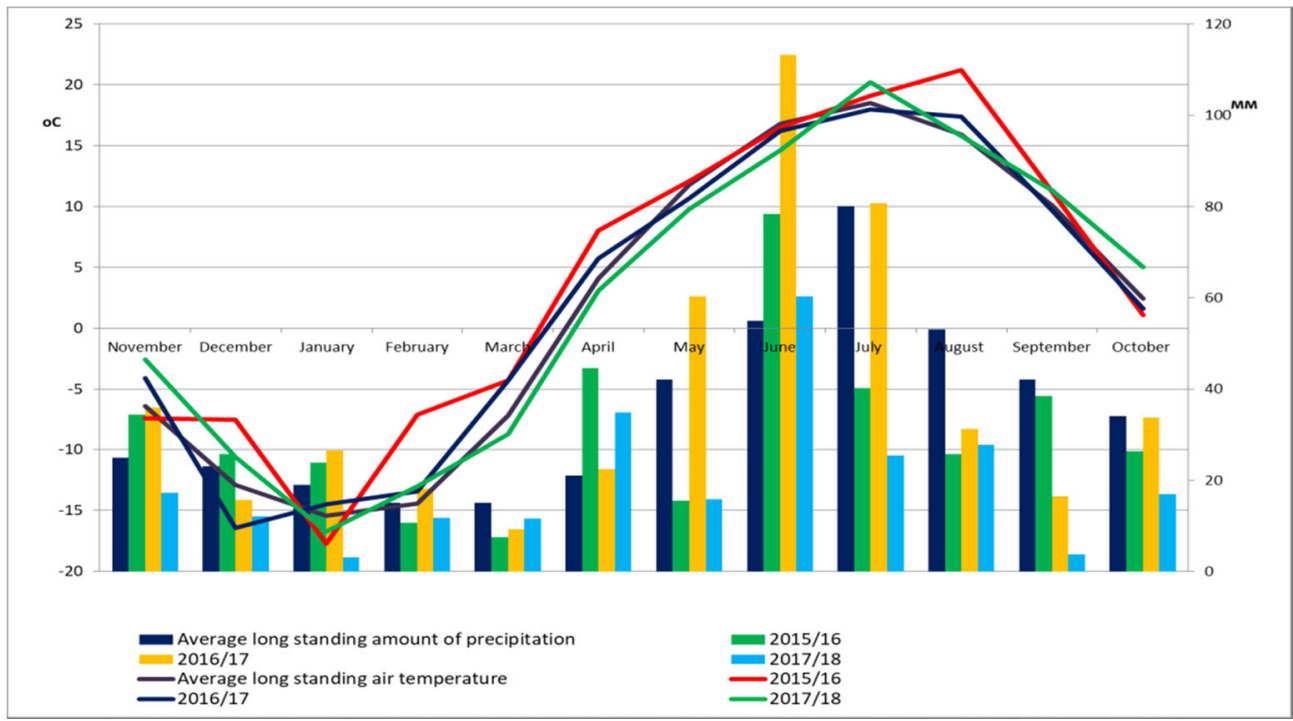

Fig. 1 Characteristics of climatic conditions in the years of research (according to returns of the Federal state University of Chelyabinsk center for Hydrometeorology and environmental monitoringweather station in Brodokalmak village, Krasnoarmeysky district, Chelyabinsk region).

During the research period, samples of sorts 'Alma', G 7-116, 9-266 had a degree of freezing to 1.8 mark, the others genotypes no more than 1.0 mark. The nature of the damages - freezing of yearling shoots. In the winter period of 2017/18 was noted a freezing of generative buds by all forms from 2.5 to 3.0 points (25-50\% death of buds), which negatively affected to the crop productivity. During the years of research was noted dry periods on the period of mass ripening of plum fruits and in the autumn, when preparing plants for wintering. Insufficient provision of moisture in July and August was noted in 
2016 - less than the norm by $52.9 \mathrm{~mm}$ and in 2018 - less than the norm by $183.3 \mathrm{~mm}$, which affected by decrease in the average weight of fruits and their taste qualities.

On the results of many years of research it was fixed that the beginning of vegetation - the opening of vegetative buds by the studied genotypes of $P$. cerasifera var. pissardii begins before flowering by 2-3 days. Plants in this phase look very impressive with purple-red blossoming leaves. Flowering by conditions of Southern Urals begins from may 06 to may 15 and lasts 5-10 days. The timing of flowering depends on weather conditions. So in 2018 flowering from behind prolonged cool weather came on may 21-23 and stretched to June 24.

With the purpose to provide the population with fresh plum fruits for a long period of time was carried out the evaluation by samples of sorts by their maturation dates (table 1). In the conditions of the Southern Urals, early fruit maturation from August 10 have sorts 'Duduka', 'Alma', N 11-175, the average maturation period - from August 21 to August 30 by five genotypes, the mid-late period maturation (September 05) by G 7-116. Regardless from the weather conditions of the growing season remains the order of fruit maturation by the studied hybrids.

Table 1. The time of fruit ripening by hybrids P. cerasifera var. pissardii, (2016-2019)

\begin{tabular}{|l|l|c|c|}
\hline \multirow{2}{*}{ Sample of the sort } & \multicolumn{2}{|c|}{ August } & September \\
\cline { 2 - 4 } & II ten-day period & III ten-day period & I ten-day period \\
\hline 'Alma' & & & \\
\hline 'Duduka' & & & \\
\hline N 11-175 & & & \\
\hline 9-266 & & & \\
\hline 'Pissarda large' & & & \\
\hline G 8-166 & & & \\
\hline G 9-146 & & & \\
\hline P 3-92 & & & \\
\hline G 7-116 & & & \\
\hline
\end{tabular}

To the research results (table 2) crop capacity of sorts essentially differed until from 3.6 to $16.1 \mathrm{~kg} /$ tree. Economically justified crop capacity of more than 40 hundredweight/ha for samples of sorts 'Duduka', G 7-116, G 8-166, G 9-146, 9-266. The best by crop capacity were 'Duduka' (15.5 kg/tree) and 9-266 (16.1 kg/tree).

By eight hybrid forms the fruits have a rounded shape (figure 2), in G 7-116 - elongatedovoid (figure 3).

Table 2. Brief economicy-biological characteristics of samples of sorts

\begin{tabular}{|c|c|c|c|c|c|c|c|c|}
\hline \multirow{3}{*}{$\begin{array}{l}\text { Sample of } \\
\text { the sort }\end{array}$} & \multirow{2}{*}{\multicolumn{2}{|c|}{ Crop capacity }} & \multicolumn{4}{|c|}{ Fruit } & \multirow{3}{*}{ 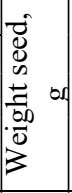 } & \multirow{3}{*}{ 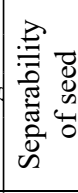 } \\
\hline & & & \multicolumn{2}{|c|}{ Weight, $g$} & \multirow{2}{*}{ form } & \multirow{2}{*}{ 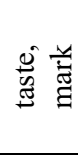 } & & \\
\hline & $\mathrm{kg} /$ tree & $\begin{array}{c}\text { hundr. - } \\
\text { weight/ha }\end{array}$ & medium & 㞼 & & & & \\
\hline 'Alma' & 4.1 & 27.3 & 17.0 & 20.0 & rounded & 4.2 & 0.7 & - \\
\hline 'Duduka' & 15.5 & 103.2 & 29.2 & 39.1 & rounded & 4.4 & 2.0 & - \\
\hline 'Pissarda large' & 3.6 & 23.9 & 12.7 & 16.0 & rounded & 4.0 & 0.6 & \\
\hline G 7-116 & 7.2 & 47.9 & 26.7 & 38.2 & $\begin{array}{l}\text { elongated- } \\
\text { egged }\end{array}$ & 4.3 & 1.7 & $*$ \\
\hline G 8-166 & 7.3 & 48.6 & 13.5 & 17.0 & rounded & 4.2 & 0.7 & $*$ \\
\hline G 9-146 & 8.8 & 58.6 & 14.8 & 17.0 & $\begin{array}{l}\text { elongated- } \\
\text { rounded }\end{array}$ & 4.3 & 0.4 & $*$ \\
\hline P 3-92 & 4.6 & 30.6 & 10.3 & 14.8 & rounded & 3.8 & 0.9 & + \\
\hline N 11-175 & 3.8 & 25.3 & 10.2 & 12.0 & rounded & 3.8 & 0.6 & - \\
\hline
\end{tabular}




\begin{tabular}{|l|l|l|l|l|l|l|l|l|}
\hline 9-266 & 16.1 & 107.2 & 14.8 & 18.2 & rounded & 3.9 & 0.6 & - \\
\hline
\end{tabular}

Comment: - - separates poorly, +- separates medium, ${ }^{*}-$ does not separate

The average mass of fruits the studied forms is varies depending on the genotype and climatic conditions during the growing season. In dry years some samples of sorts may be a slight bitterness in the skin of the fruit. Small fruits from $10.2 \mathrm{~g}$ (N 11-175) to $14.8 \mathrm{~g}$ (9266) have six hybrid forms. Large-fruited are - 'Duduka' (29.2 g) and G 7-116 (26.7 g).

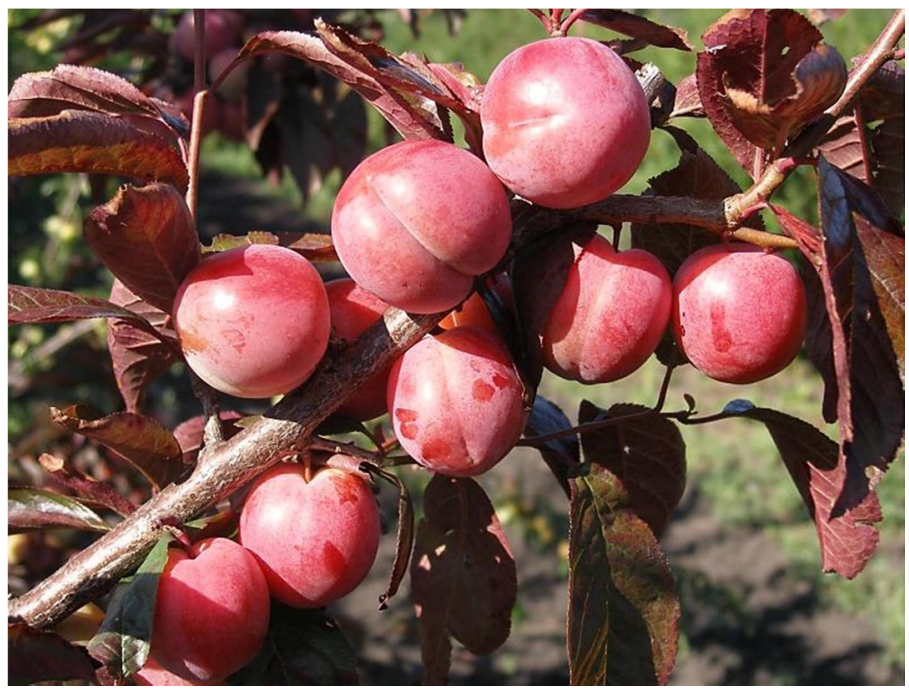

Fig. 2. Fruits of the selected form of 'Duduka' (Photo Makarenko S.A.)

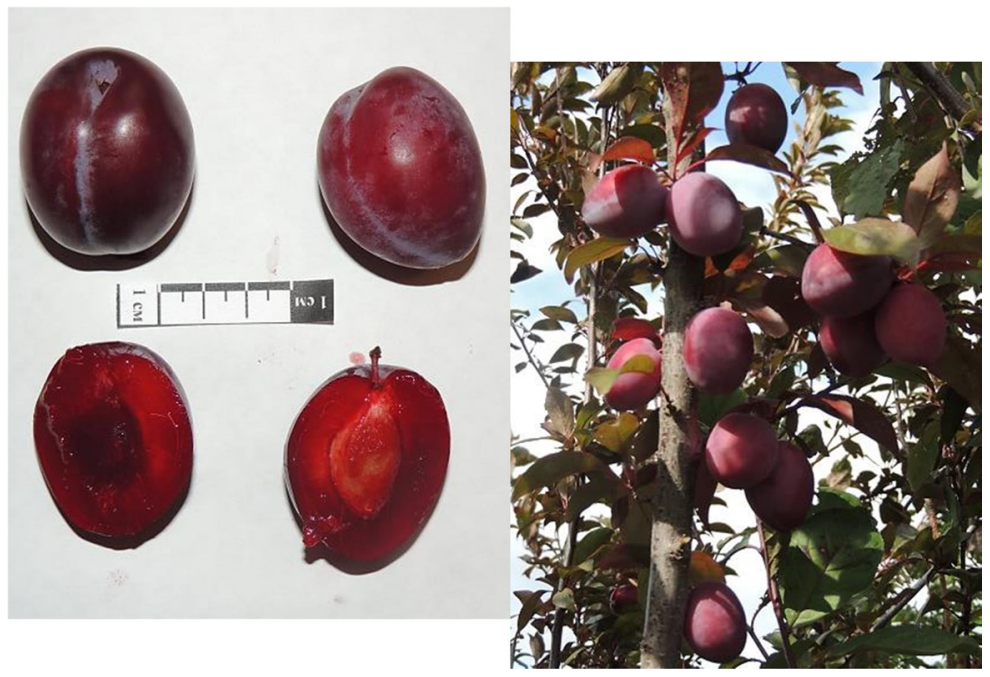

Fig. 3. Fruits of the selected form G 7-116 (Photo Slepneva T.N., Makarenko S.A.)

The maximum mass by these selection forms was noted in 2019 with sufficiently moisture during the ripening period - 'Duduka' (39.1 g) and G 7-116 (38.2 g). 
Wide polymorphism by the studied of samples sorts differs in the taste of fruits from 3.8 to 4.4 mark. Good fruit taste has samples of the sort 'Duduka' (4.4 mark), G 7-116 (4.3 mark), G 9-146 (4.3 mark). Fruit pulp with anthocyanin color has great value in selection for increasing the content of biologically active substances. All selection forms have this feature.

By results of the evaluation of the growth strength tree, all the studied derivations of $P$. cerasifera var. pissardii are classified as low-growing and medium-growing (table 3 ).

By results the researchs the genotypes - 'Duduka', P 3-92, G 8-166, N 11-175 have low-growing trees, the height of which varies from $2.8 \mathrm{~m}$ (P 3-92) to $3.0 \mathrm{~m}$ ('Duduka'), this simplifies crown care and reduces the costs of harvesting. The group of medium-sized included five genotypes, where is the highest height by 9-266 $(4.5 \mathrm{~m})$. The volume crown varies from $4.2 \mathrm{~m}^{3}$ (P 3-92) to $17.8 \mathrm{~m}^{3}(9-266)$.

Table 3. Biometric indicators of samples sorts, 2019 г.

\begin{tabular}{|c|c|c|c|c|c|c|c|c|}
\hline \multirow[b]{2}{*}{$\begin{array}{l}\text { Sample of } \\
\text { the sort }\end{array}$} & \multirow[b]{2}{*}{$\begin{array}{c}\text { Tree } \\
\text { height, } \\
\mathrm{m}\end{array}$} & \multirow{2}{*}{$\begin{array}{c}\text { Trunk } \\
\text { height, } \\
\text { M }\end{array}$} & \multicolumn{3}{|c|}{ Crown width, $\mathrm{m}$} & \multirow[b]{2}{*}{\begin{tabular}{ll}
\multirow{3}{3}{} & 0 \\
0 & 0 \\
0 & 0 \\
0
\end{tabular}} & \multirow{2}{*}{$\begin{array}{c}\text { S projection } \\
\text { of the crown, } \\
\mathrm{m}^{2}\end{array}$} & \multirow{2}{*}{$\begin{array}{c}\text { The volume } \\
\text { of the crown, } \\
\mathrm{m}^{3}\end{array}$} \\
\hline & & & $\begin{array}{l}\text { along } \\
\text { the } \\
\text { row }\end{array}$ & $\begin{array}{l}\text { across } \\
\text { the row }\end{array}$ & $\bar{x}$ & & & \\
\hline \multicolumn{9}{|c|}{ Low-growing (tree height $2,10-3,0 \mathrm{~m}$ ) } \\
\hline P 3-92 & 2.8 & 0.34 & 2.8 & 1.7 & 2.2 & 03 & 3.8 & 4.2 \\
\hline G 8-166 & 2.9 & 0.23 & 2.0 & 2.2 & 2.1 & 02 & 3.4 & 6.1 \\
\hline N 11-175 & 2.9 & 0.26 & 2.9 & 2.8 & 2.8 & 04 & 6.1 & 7.2 \\
\hline 'Duduka' & 3.0 & 0.15 & 2.8 & 2.4 & 2.6 & 03 & 5.3 & 6.8 \\
\hline \multicolumn{9}{|c|}{ Medium-growing (tree height $3,1-6,0 \mathrm{~m}$ ) } \\
\hline G 9-146 & 3.1 & 0.24 & 2.9 & 2.2 & 2.5 & 05 & 4.9 & 9.4 \\
\hline 'Alma' & 3.1 & 0.11 & 2.6 & 2.1 & 2.3 & 02 & 4.1 & 8.2 \\
\hline 'Pissarda large' & 3.1 & 0.20 & 3.1 & 2.2 & 2.6 & 03 & 5.3 & 6.9 \\
\hline G 7-116 & 3.3 & 0.10 & 2.7 & 2.5 & 2.6 & 05 & 5.3 & 11.4 \\
\hline $9-266$ & 4.5 & 0.7 & 3.6 & 2.5 & 3.0 & 02 & 7.0 & 17.8 \\
\hline
\end{tabular}

The studied forms of $P$. cerasifera var. pissardii have different types of crowns.

Stack-shape of the crown has 'Duduka', 'Pissarda large', P 3-92; oval-shape crown 'Alma', 9-266, G 8-166; broom-shape - G 7-116, G 9-146; drooping-shape N 11-175.

\section{Conclusions}

Accordingly, in the conditions of the forest-steppe of the southern Urals, selected forms of the hybrid $P$. cerasifera var. pissardii were selected for the complex of economic and useful characteristics and recommended for involvement in selection as sources of valuable features:

- 'Duduka'(large fruit size, crop capacity, taste of fruit, low growing);

- G 7-116 large fruit size, taste of fruit, crop capacity, late ripening period.

For the production study was selected sample G 7-116.

\section{References}

1. V.M. Gorina, A.A. Richter, G.P. Zaitsev Cultivation and protection of rights to plant sorts. 2, (2011):36-41.

2. G.V Eremin, Subtropical and ornamental gardening.70, (2019):37-42. 
3. G.V.Eremin, A.S. Hasanov New decorative varieties of stone fruit plants. Chelyabinsk: Scientific and production Association. Garden and vegetable garden, (Russia, 2012).

4. E.V. Dunaevskaya, V.M. Gorina, O.A. Grebennikova Biological value by fruits of Plum varieties Idyll, Krasnomyasaya and Piccardi large-fruited in Proceedings of the Kuban state agrarian University, 67, (2017):43-47.

5. E.P. Shofritov Bulletin of DPB, 109, 43-50 (2013).

6. A.A. Vasiliev, Pomology by sorts of fruit and berry, vegetable crops and potatoes selection of the South Ural research Institute of horticulture and potato production. (Chelyabinsk: FSBS SURIHP, Russia, 2018)

7. M.N. Matyunin, Biological features and selection of stone crops in the Altai Mountains (Novosibirsk, Russia, 2016).

8. E.N. Jigadlo, A.F. Kolesnikov, G.V. Eremin, T.V. Morozova, S.Y. Debishev, M.V. Kanshina, N. Medvedev \& V.S. Simagin Stone cultures. In the book: Program and method by sorts-study of fruit, berry and nut crops. (Orel, All-Russian research Institute of fruit crop selection, Russia, 1999).

9. V.L. Vitkovsky, K.D. Melnikova, Z.M. Gavrilina, V.A. Korneychuk Wide unified classifier of CMEA of the genus Prunus L. (Leningrad: ARRIPG, Russia, 1978).

10. V.A. Potapov, A.I. Zavrazhnov, V.N. Petrushin Biometrics of fruit fruit cultures. (Michurinsk: Federal State Budgetary Educational Institution of Higher Education Michurinsk State Agrarian University, Russia, 2004). 